\title{
ROZWÓJ EKONOMICZNY POWIATÓW WOJEWÓDZTWA MAZOWIECKIEGO - ANALIZA WIELOWYMIAROWA
}

\author{
Tomasz Siudek, Katarzyna Drabarczyk \\ Katedra Finansów Szkoły Głównej Gospodarstwa Wiejskiego w Warszawie \\ Kierownik katedry: dr hab. Mirosław Wasilewski, prof. SGGW

\begin{abstract}
Słowa kluczowe: rozwój ekonomiczny, wskaźnik syntetyczny, powiaty
Key words: economic development, synthetic indicator, counties

S y n o p s i s. Celem pracy było określenie poziomu rozwoju ekonomicznego powiatów województwa mazowieckiego przy wykorzystaniu autorskiego wskaźnika syntetycznego. Z uzyskanych danych wynika, że najlepszymi powiatami pod względem rozwoju ekonomicznego w latach 2006-2015 były miasta na prawach powiatu: Warszawa, Płock i Ostrołęka oraz powiaty graniczące z Warszawą: piaseczyński i pruszkowski. Z kolei najgorszymi powiatami pod względem rozwoju ekonomicznego były powiaty położone na południu i wschodzie województwa mazowieckiego: lipski, przysuski, zwoleński, siedlecki i szydłowiecki.
\end{abstract}

\section{WSTĘP}

W momencie wyodrębnienia się ekonomii jako dyscypliny naukowej systemy gospodarcze stały się istotnym przedmiotem zainteresowań naukowców. Pierwsze badania koncentrowały się nad rozpoznaniem czynników wpływających na wzrost bogactwa narodów. Zaczęto poszukiwać przyczyn sukcesów jednych gospodarek i niepowodzeń drugich. Wraz z rozwojem badań nad problemami gospodarczymi ukształtowało się ogólne pojęcie rozwoju. Początkowo rozwój gospodarczy czy też ekonomiczny utożsamiany był ze wzrostem gospodarczym. Dopiero później ekonomiści uznali, że rozwój nie jest tylko zmianą ilościową, jak w przypadku wzrostu gospodarczego, ale wiąże się również z jakościową zmianą gospodarki.

Radosław Pastusiak definiuje rozwój gospodarczy jako długofalowy proces, kształtowany zjawiskami natury ekonomicznej, społecznej i ekologicznej, polegający na zmianach, które prowadzą do wyższego stanu bogactwa większości obywateli [Pastusiak 2011]. Według Gunnara Myrdala, rozwój gospodarczy to wzrost całego systemu społeczno-gospodarczego, nie tylko produkcji, ale także poprawa poziomu życia ludności, funkcjonowania instytucji czy też zmiany postaw ludzkich [Myrdal 1973]. Ryszard Piasecki uważa, że rozwój gospodarczy to zmiany ilościowe i jakościowe w dziedzinach gospodarki, polityki, instytucji, kultury czy też technologii [Piasecki 2003]. Większość definicji zwraca uwagę na fakt, że rozwój gospodarczy to proces rozłożony na lata, obejmujący zmiany ilościowo-jakościowe, które wywołują poprawę bytu życia ludności. Z literatury przedmiotu wynika, że niektóre z podejść badania rozwoju gospodarczego koncentrują na jego elementach, podczas gdy inne wskazują 
na narzędzia i metody niezbędne do jego osiągnięcia. Podsumowując, należy stwierdzić, że rozwój gospodarczy jest procesem kreowania nowych miejsc pracy, powiększania dochodów i bogactwa społeczeństw, czego efektem jest wzrost jakości życia ludności.

Określenie poziomu rozwoju może być przydatne przy kształtowaniu polityki społeczno-gospodarczej. Samorządy jednostek terytorialnych powinny uwzględniać w swoich strategiach mocne i słabe strony rozwoju gospodarczego, przez co będą mogły ukierunkowywać działania na zmniejszanie dysproporcji rozwojowych w stosunku do innych jednostek.

\section{CEL, ZAKRES I METODY BADAŃ}

Głównym celem badań było określenie poziomu rozwoju ekonomicznego powiatów województwa mazowieckiego przy wykorzystaniu autorskiego wskaźnika syntetycznego. Badania obejmowały lata 2006-2015. Zebrane dane pochodziły z Banku Danych Lokalnych GUS. Do badania przyjęto 15 zmiennych $^{1}$ :

$x_{1}$ - dochody budżetów powiatów na 1 mieszkańca (zł),

$x_{2}$ - wydatki budżetów powiatów na 1 mieszkańca (w działach: rolnictwo i łowiectwo, transport i łączność, gospodarka mieszkaniowa) (zł),

$x_{3}$ - przeciętna powierzchnia użytkowa mieszkania na 1 osobę $\left(\mathrm{m}^{2}\right)$,

$x_{4}$ - udział mieszkań wyposażonych w wodociąg w ogólnej liczbie mieszkań (\%),

$x_{5}$ - udział mieszkań wyposażonych w łazienkę w ogólnej liczbie mieszkań (\%),

$x_{6}$ - udział mieszkań wyposażonych w centralne ogrzewanie w ogólnej liczbie mieszkań (\%),

$x_{7}-$ zużycie gazu z sieci na 1 mieszkańca $\left(\mathrm{m}^{3}\right)$,

$x_{8}$ - zużycie energii elektrycznej na 1 mieszkańca $(\mathrm{kWh})$,

$x_{9}$ - liczba nowych mieszkań oddanych do użytku na 1000 ludności,

$x_{10}$ - liczba podmiotów wpisanych do rejestru REGON na 10 tys. ludności,

$x_{11}$-długość dróg gminnych i powiatowych o twardej nawierzchni na $100 \mathrm{~km}^{2}(\mathrm{~km})$,

$x_{12}$ - przeciętne miesięczne wynagrodzenie brutto w relacji do średniej krajowej (\%),

$x_{13}$ - liczba miejsc noclegowych w turystycznych obiektach noclegowych na 1000 osób,

$x_{14}$ - nakłady inwestycyjne w przedsiębiorstwach na 1 mieszkańca (zł),

$x_{15}$ - wartość brutto środków trwałych w przedsiębiorstwach na 1 mieszkańca (zł).

W celu oszacowania wskaźnika syntetycznego rozwoju ekonomicznego powiatów województwa mazowieckiego zastosowano analizę czynnikową. Istota tej analizy polegała na przekształceniu liniowym $n$-zmiennych pierwotnych $X_{i}(i=1, \ldots, n)$ na $t$ nowych zmiennych wtórnych $U_{k}(k=1, \ldots, t)$, które są wzajemnie nieskorelowane, a suma ich wariancji jest równa sumie wariancji zmiennych pierwotnych $X_{i}$. Zmienne $U_{k}$ nazwane są czynnikami głównymi, a ich wariancja wyjaśnia pewną część zmienności cech pierwotnych, która wyrażana jest przez wartość własną. Kolejne wyodrębnione czynniki główne wyjaśniały coraz mniej zmienności. W celu ich wyodrębnienia w badaniach zastosowano kryterium Kaisera. Za główne składowe przyjęto te czynniki, dla których wartość własna była wyższa od 1 .

\footnotetext{
Dobór zmiennych pierwotnych do badań uwarunkowany był głównie zasobami informacji o rozwoju powiatów w Polsce w bazie danych lokalnych GUS. Wszystkie zmienne pierwotne wykorzystane w badaniach są stymulantami.
} 
Wartości czynników głównych² i wartości wskaźnika syntetycznego rozwoju ekonomicznego powiatów województwa mazowieckiego obliczano według następujących równań:

$$
U_{k}=a_{1 k} x_{1}+a_{2 k} x_{2}+a_{3 k} x_{3}+\ldots a_{n k} x_{n}
$$

gdzie: $U_{k}$ - wartość $k$-tego czynnika głównego, $k=1,2, \ldots t, a_{i k}-$ oszacowane wagi składowe $i$-tych zmiennych pierwotnych przy $k$-tym czynniku głównym, $x_{i}-$ wartość $i$-tej zmiennej pierwotnej, $i=1,2, \ldots n$,

$$
W_{s}=b_{1} U_{1}+b_{2} U_{2}+b_{3} U_{3}+\ldots b_{t} U_{t}
$$

gdzie: $W_{s}$ - wskaźnik syntetyczny rozwoju ekonomicznego powiatów województwa mazowieckiego, $b_{k}$ - oszacowane wagi składowe $k$-tych czynników głównych, odzwierciedlające określony procent zmienności, $k=1,2, \ldots t, U_{k}$-wartość $k$-tego czynnika głównego, $k=1,2, \ldots t$.

\section{ROZWÓJ EKONOMICZNY W ŚWIETLE BADAŃ EMPIRYCZNYCH NA ŚWIECIE}

Z przeglądu literatury wynika, że badania dotyczące rozwoju gospodarczego prowadzone są od wielu lat, zarówno w ujęciu międzynarodowym, krajowym, regionalnym, jak i lokalnym. Część badań dotyczy pomiaru poziomu rozwoju, pozostałe zaś głównie identyfikują jego determinanty. Ze względu na to, że do tej pory nie stworzono jednej powszechnie akceptowanej metody pomiaru rozwoju gospodarczego, w literaturze przedmiotu można odnaleźć ich wiele.

Tomasz Siudek badał poziom i czynniki rozwoju gospodarczego w wybranych krajach na świecie w 2011 roku. Najwyższy poziom rozwoju gospodarczego mierzony PKB per capita wykazywały takie kraje, jak: Luksemburg, Norwegia, Katar, Szwajcaria, Kuwejt i Australia. Polska z wynikiem 13,5 tys. dolarów zaliczała się do krajów o niskim PKB na 1 mieszkańca [Siudek 2013]. Według innych mierników rozwoju gospodarczego, takich jak HDI, LPI i HPI ${ }^{3}$, Polska zajmowała odpowiednio: 39., 28. i 77. miejsce wśród badanych 173 krajów.

Małgorzata Stec badała poziom rozwoju gospodarczego w Polsce na tle krajów Unii Europejskiej (UE). Podstawą analizy porównawczej krajów był PKB per capita oraz wskaźnik syntetyczny, wyznaczony metodą standaryzowanych sum, który obejmował cechy demograficzne, cechy rozwoju przemysłu i rolnictwa oraz cechy infrastruktury społeczno-technicznej. W wyniku przeprowadzonych badań autorka stwierdziła, że w porównaniu do krajów UE-15 Polskę dzieli znaczny dystans rozwojowy [Stec 2004].

Iwona Pawlas charakteryzowała rozwój gospodarczy w krajach UE w latach 2004 i 2013. Na podstawie miary rozwoju Hellwiga i metody Warda stwierdziła, że w UE utrzymuje się wyraźne zróżnicowanie krajów pod względem rozwoju gospodarczego. W całym badanym okresie Luksemburg charakteryzował się najwyższym rozwojem gospodarczym, mierzonym syntetyczną miarą TMR. W czołówce znalazły się także takie kraje, jak: Szwecja, Dania i Holandia. W 2004 roku najsłabszymi krajami UE pod względem

\footnotetext{
$2 \quad$ Przed wyznaczeniem wartości czynników głównych i wskaźnika syntetycznego zmienne pierwotne były standaryzowane. Czynniki główne są stymulantami - im większa ich wartość, tym wyższy rozwój ekonomiczny powiatów województwa mazowieckiego. Znak ujemny lub dodatni przy wagach zmiennych pierwotnych poszczególnych czynników głównych oznacza destymulantę lub stymulantę (tab. 3.).

3 HDI - Human Development Index; LPI - Legatum Prosperity Index; HPI - Happy Planet Index.
} 
rozwoju gospodarczego były: Rumunia, Bułgaria i Polska, a w 2013 roku: Grecja, Bułgaria i Rumunia. Polska awansowała z 25. pozycji na 16 . Na podstawie uzyskanych wyników badaczka stwierdziła, że w badanym okresie zmniejszył się dystans dzielący Polskę od krajów UE-15 pod względem rozwoju gospodarczego [Pawlas 2015].

Cesar Calderon i Lius Serven określili wpływ jakości infrastruktury na rozwój gospodarczy 36 krajów afrykańskich w relacji do 64 krajów na świecie w latach 1960-2005. Wskazali oni, że rozwój infrastruktury ma pozytywny wpływ na długoterminowy rozwój gospodarczy wszystkich badanych krajów [Calderon, Serven 2008].

Do podobnych wniosków doszli Shenggen Fan i Xiaobo Zhang, badając wpływ infrastruktury na rozwój gospodarczy w Chinach. Na podstawie przeprowadzonych badań wykazali, że to działalność nierolnicza jest głównym czynnikiem decydującym o dochodach na wsi. Konkludując, stwierdzili, że inwestowanie w infrastrukturę obszarów wiejskich jest głównym czynnikiem stymulującym wzrost dochodów ludności wiejskiej [Fan, Zhang 2004].

Hyun Jeong Kim, Chen Ming-Hsiang i Jang SooCheong badali związek przyczynowo-skutkowy między rozwojem turystyki a rozwojem gospodarczym Tajwanu w latach 1956-2002. Na podstawie uzyskanych wyników stwierdzili, że turystyka pobudza rozwój gospodarczy i na odwrót [Kim i in. 2006].

Shujie Yao określił rozwój gospodarczy w Chinach w latach 1978-1996, wykorzystując wskaźnik PKB. Zauważył, że poziom ubóstwa na wsi w badanym okresie obniżył się z 75 do 7\%, co uznał za bezprecedensowy wynik w historii rozwoju światowego [Yao 2000].

T. Siudek określił wpływ kredytów rolniczych udzielanych przez banki spółdzielcze na rozwój rolnictwa w Polsce i wskazał, że wystąpiła dodatnia współzależność między poziomem wskaźnika udziału kredytów rolniczych w aktywach ogółem banków spółdzielczych a poziomem rozwoju rolnictwa [Siudek 2008].

Z literatury przedmiotu wynika, że wielu badaczy analizowało również związek między liczbą ludności a rozwojem gospodarczym. Derek Headey i Andriew Hodge stwierdzili, że szybki wzrost liczby ludności miał negatywny wpływ na rozwój gospodarczy krajów rozwijających się [Headey, Hodge 2009]. Tim Dyson wykazał, że główną przyczyną rozwoju gospodarczego krajów jest spadek śmiertelności ludności [Dyson 2010]. Zdaniem Thomasa McKeowna poprawa standardu życia ludności powoduje obniżenie ich poziomu śmiertelności [McKeown 1976]. David Bloom i David Canning wykazali, że starzenie się ludności ma negatywny wpływ na rozwój gospodarczy [Bloom, Canning 2009]. Steven Sindig zaznaczył, że poprawa warunków życia ludności prowadzi do niższych wskaźników urodzeń, a tym samym niższego rozwoju gospodarczego [Sindig 2009]. Z kolei Julian Simon na podstawie wyników badań stwierdził, że wzrost liczby ludności może mieć pozytywny wpływ na wzrost PKB per capita w perspektywie długoterminowej [Simon 1981].

$\mathrm{W}$ badaniach istotnym czynnikiem mającym wpływ na rozwój gospodarczy jest poziom wykształcenia ludności. Panagiotis Pegkas na przykładzie Grecji stwierdził, że istnieje długoterminowa relacja między poziomem wykształcenia ludności a poziomem PKB. Wykazał on, że poziom szkolnictwa średniego i wyższego miał statystycznie istotny wpływ na rozwój gospodarczy, a poziom podstawowego szkolnictwa takiego wpływu nie miał [Pegkas 2014]. Podobne badania przeprowadzone w krajach afrykańskich wykazały, że wraz ze wzrostem udziału ludności z wyższym wykształceniem wzrasta dochód na 1 mieszkańca [Gyimah-Brempong i in. 2006]. D. Bloom z zespołem potwierdzili, że inwestowanie w szkolnictwo wyższe w Afryce przyczynia się do rozwoju technologicznego, a tym samym do spadku poziomu ubóstwa [Bloom i in. 2014]. Panagiotis Petrakis i Dimitrios Stamatakis analizowali 
związek między kapitałem ludzkim a rozwojem gospodarczym w wybranych krajach OECD. Uzyskane wyniki wykazały, że rola szkolnictwa podstawowego i średniego w rozwoju gospodarczym jest większa w krajach rozwijających się niż rozwiniętych. W tych ostatnich o rozwoju gospodarczym decyduje głównie szkolnictwo wyższe [Petrakis, Stamatakis 2002].

\section{ROZWÓJ EKONOMICZNY POWIATÓW WOJEWÓDZTWA MAZOWIECKIEGO - WYNIKI BADAŃ}

W celu oszacowania poziomu rozwoju ekonomicznego powiatów województwa mazowieckiego wykorzystano 15 zmiennych objaśniających. W wyniku analizy czynnikowej spośród zmiennych pierwotnych wyodrębniono 3 czynniki główne, które wyjaśniały 77,35\% ogólnej zmienności. Czynniki pierwszy, drugi i trzeci odzwierciedlały odpowiednio 51, 18 i 7\% ogólnej zmienności (tab. 1.).

Na czynnik pierwszy najsilniejszy wpływ miały takie zmienne pierwotne, jak dochody i wydatki budżetów powiatów na 1 mieszkańca. Ładunki czynnikowe wymienionych zmiennych pierwotnych wynosiły odpowiednio 0,94 i 0,85 (tab. 2.). Na czynnik drugi największy wpływ wywierały: zużycie energii elektrycznej na 1 mieszkańca $(0,93)$ i zużycie gazu na 1 mieszkańca $(0,91)$, a na czynnik trzeci: udział mieszkań wyposażonych w wodociąg i w łazienkę w ogólnej liczbie mieszkań (odpowiednio 0,52 i 0,48).

Pod względem wartości czynnika pierwszego najwyższe miejsca $\mathrm{w}$ rankingu zajęły miasta na prawach powiatu oraz powiaty piaseczyński i pruszkowski (tab. 3.). Pod względem czynnika drugiego najlepsze były powiaty: piaseczyński, warszawski zachodni, m. Warszawa i pruszkowski. W przypadku czynnika trzeciego dominowały miasta na prawach powiatu, takie jak: Ostrołęka, Siedlce i Radom. Trzy powiaty - lipski, siedlecki i przysuski były najgorsze w ramach badanych trzech czynników.

Oprócz pojedynczych czynników duże znaczenie ma wskaźnik syntetyczny, który pozwala określić poziom rozwoju ekonomicznego powiatów województwa mazowieckiego. Na jego podstawie stwierdzono, że najwyższy poziom rozwoju wystąpił w powiecie m. Warszawa (tab. 3.). Ogólnie można stwierdzić, że pozostałe miasta na prawach powiatu (Płock, Ostrołęka i Siedlce) oraz powiaty graniczące $\mathrm{z}$ m. Warszawa (piaseczyński i pruszkowski) charakteryzowały się wysokim poziomem rozwoju ekonomicznego. Z kolei powiaty: lipski, przysuski, zwoleński, siedlecki i szydłowiecki, leżące przy granicy admi-

Tabela 1. Analiza czynnikowa rozwoju ekonomicznego powiatów województwa mazowieckiego w latach 2006-2015

\begin{tabular}{lccc}
\hline Czynnik & $\begin{array}{c}\text { Wartość } \\
\text { własna }\end{array}$ & $\begin{array}{c}\text { Procent } \\
\text { wariancji }\end{array}$ & $\begin{array}{c}\text { Procent } \\
\text { skumulowany }\end{array}$ \\
\hline 1. & $7,66^{*}$ & 51,08 & 51,08 \\
2. & $2,82^{*}$ & 18,82 & 69,90 \\
3. & $1,12^{*}$ & 7,46 & 77,35 \\
4. & 0,98 & 6,51 & 83,86 \\
5. & 0,70 & 4,67 & 88,53 \\
6. & 0,42 & 2,78 & 91,31 \\
7. & 0,34 & 2,24 & 93,55 \\
8. & 0,29 & 1,95 & 95,50 \\
9. & 0,22 & 1,46 & 96,96 \\
10. & 0,13 & 0,88 & 97,84 \\
11. & 0,11 & 0,74 & 98,58 \\
12. & 0,09 & 0,59 & 99,17 \\
13. & 0,06 & 0,39 & 99,55 \\
14. & 0,04 & 0,27 & 99,82 \\
15. & 0,03 & 0,18 & 100,00 \\
\hline
\end{tabular}

* wartość własna uznana za istotną zgodnie z kryterium Kaisera.

Spośród badanych 15 zmiennych pierwotnych wybrano 3 czynniki główne odzwierciedlające 77,35\% zmienności ogólnej.

Źródło: badania własne. 
Tabela 2. Czynniki decydujące o zróżnicowaniu rozwoju ekonomicznego powiatów województwa mazowieckiego w latach 2006-2015

Zmienne pierwotne Czynniki główne

czynnik 1 . czynnik 2 . czynnik 3 .

1. Dochody budżetów powiatów na 1 mieszkańca [zł] - $\left(x_{1}\right)$

$0,9432 \quad-0,1297 \quad 0,0385$

2. Wydatki budżetów powiatów na 1 mieszkańca (w działach: rolnictwo i łowiectwo, transport i łączność, gospodarka mieszkaniowa) [zł] $-\left(x_{2}\right)$

$0,8517 \quad-0,0520 \quad-0,1843$

3. Przeciętna powierzchnia użytkowa mieszkania na 1 osobę $\left[\mathrm{m}^{2}\right]-\left(x_{3}\right)$

$\begin{array}{lll}-0,0445 & 0,8485 & -0,2689\end{array}$

4. Udział mieszkań wyposażonych w wodociąg w ogólnej liczbie mieszkań $[\%]-\left(x_{4}\right)$

$0,6220 \quad 0,4197 \quad 0,5235$

5. Udział mieszkań wyposażonych w łazienkę w ogólnej liczbie mieszkań $[\%]-\left(x_{5}\right)$

$0,6585 \quad 0,5108 \quad 0,4835$

6. Udział mieszkań wyposażonych w centralne ogrzewanie w ogólnej liczbie mieszkań $[\%]-\left(x_{6}\right)$

$0,6854 \quad 0,4894 \quad 0,4582$

7. Zużycie gazu z sieci na 1 mieszkańca $\left[\mathrm{m}^{3}\right]-\left(x_{7}\right)$

$0,1590 \quad 0,9126 \quad 0,1343$

8. Zużycie energii elektrycznej na 1 mieszkańca $[\mathrm{kWh}]-\left(x_{8}\right)$

9. Liczba nowych mieszkań oddanych do użytku na 1000 ludności - $\left(x_{9}\right)$

$0,0356 \quad 0,9277 \quad-0,0591$

10.Liczba podmiotów wpisanych do rejestru REGON na 10 tys. ludności $-\left(x_{10}\right)$

$0,1825 \quad 0,7803 \quad 0,0625$

$0,5756 \quad 0,7185 \quad 0,0383$

11.Długość dróg gminnych i powiatowych o twardej nawierzchni na $100 \mathrm{~km}^{2}[\mathrm{~km}]-\left(x_{11}\right)$

$0,8431 \quad 0,0926 \quad 0,2340$

12.Przeciętne miesięczne wynagrodzenie brutto $\mathrm{w}$ relacji do średniej krajowej [\%] $-\left(x_{12}\right)$

$0,7102 \quad 0,5013 \quad-0,0931$

13.Liczba miejsc noclegowych w turystycznych obiektach noclegowych na 1000 ludności - $\left(x_{13}\right)$

$0,2130 \quad 0,1976 \quad-0,5442$

14.Nakłady inwestycyjne w przedsiębiorstwach na 1 mieszkańca $[\mathrm{zł}]-\left(x_{14}\right)$

$0,7002 \quad 0,2045 \quad-0,1474$

15.Wartość brutto środków trwałych w przedsiębiorstwach na 1 mieszkańca $[\mathrm{zl}]-\left(x_{15}\right)$

$0,8119 \quad 0,2802 \quad-0,0836$

$x_{i}$ - wartość $i$-tej zmiennej pierwotnej, $i=1,2,3, \ldots 15 ; U_{k}$ - wartość $k$-tego czynnika głównego, $k=1,2,3$.

Źródło: badania własne.

nistracyjnej województwa charakteryzowały się najniższym rozwojem ekonomicznym. Ujemnymi wartościami wskaźnika syntetycznego charakteryzowały się powiaty ziemskie leżące na południu, wschodzie i północnym-wschodzie województwa mazowieckiego.

W tabeli 4. zawarto wartości wskaźnika syntetycznego rozwoju ekonomicznego powiatów województwa mazowieckiego w latach 2006-2015. Porównując wartości wskaźnika w latach 2006 i 2015, można stwierdzić, że największy jego wzrost odnotowano w powiecie kozienickim $(5,17)$ i w m. Warszawa $(4,22)$, a najmniejszy w powiecie gostynińskim $(1,34)$ i powiecie legionowskim $(1,42)$. W 2006 roku różnica między powiatem o najwyższym i najniższym rozwoju ekonomicznym wynosiła 17,48, a w 2015 roku 19,34. W 2006 roku najwyższy rozwój ekonomiczny wykazywało $\mathrm{m}$. Warszawa, a najniższy powiat lipski. W 2015 roku ponownie najlepsze było $\mathrm{m}$. Warszawa, najgorszy zaś był powiat przysuski. Na 
Tabela 3. Ranking powiatów województwa mazowieckiego pod względem wartości czynników głównych i wskaźnika syntetycznego rozwoju ekonomicznego w latach 2006-2015

\begin{tabular}{|c|c|c|c|c|c|c|c|c|}
\hline Powiaty & $\begin{array}{c}\text { Czynnik } \\
1 .\end{array}$ & Pozycja & $\begin{array}{c}\text { Czynnik } \\
2 .\end{array}$ & Pozycja & $\begin{array}{c}\text { Czynnik } \\
3 .\end{array}$ & Pozycja & $\mathrm{W}_{\mathrm{s}}$ & Pozycja \\
\hline m. Warszawa & 23,2969 & 1 & 10,7723 & 3 & 0,8398 & 11 & 13,990 & 1 \\
\hline m. Płock & 14,3800 & 2 & 2,8013 & 9 & 1,9031 & 4 & 8,015 & 2 \\
\hline m. Ostrołęka & 11,4693 & 3 & 1,9737 & 12 & 3,1772 & 1 & 6,467 & 3 \\
\hline piaseczyński & 6,4698 & 7 & 13,3336 & 1 & 0,9836 & 8 & 5,887 & 4 \\
\hline pruszkowski & 6,8152 & 5 & 9,5987 & 4 & 1,6319 & 5 & 5,409 & 5 \\
\hline m. Siedlce & 8,8547 & 4 & 2,3533 & 10 & 2,7974 & 2 & 5,175 & 6 \\
\hline $\begin{array}{l}\text { warszawski } \\
\text { zachodni }\end{array}$ & 4,9822 & 8 & 12,3587 & 2 & 0,8976 & 10 & 4,937 & 7 \\
\hline legionowski & 3,8331 & 9 & 8,4257 & 5 & 0,5561 & 16 & 3,585 & 8 \\
\hline m. Radom & 6,5820 & 6 & $-0,1393$ & 17 & 2,5944 & 3 & 3,529 & 9 \\
\hline grodziski & 2,5129 & 10 & 8,2857 & 6 & 0,9383 & 9 & 2,913 & 10 \\
\hline wołomiński & 0,8648 & 13 & 5,1952 & 7 & 1,3914 & 6 & 1,523 & 11 \\
\hline otwocki & 0,7076 & 14 & 4,7429 & 8 & 0,5399 & 17 & 1,294 & 12 \\
\hline nowodworski & 1,3977 & 11 & 2,0073 & 11 & 0,4128 & 19 & 1,123 & 13 \\
\hline kozienicki & 1,2183 & 12 & $-0,6851$ & 18 & $-1,4400$ & 34 & 0,386 & 14 \\
\hline sochaczewski & 0,1419 & 15 & 0,0603 & 16 & 0,7802 & 13 & 0,142 & 15 \\
\hline żyrardowski & $-0,1920$ & 16 & 0,4019 & 15 & 0,1314 & 23 & $-0,013$ & 16 \\
\hline grójecki & $-0,7425$ & 18 & 1,0693 & 13 & $-0,3904$ & 27 & $-0,207$ & 17 \\
\hline ciechanowski & $-0,2559$ & 17 & $-1,0102$ & 19 & 0,7051 & 14 & $-0,268$ & 18 \\
\hline miński & $-1,9466$ & 21 & 0,7107 & 14 & 0,0996 & 24 & $-0,853$ & 19 \\
\hline wyszkowski & $-1,7110$ & 19 & $-1,7167$ & 20 & 0,2663 & 20 & $-1,177$ & 20 \\
\hline mławski & $-1,8169$ & 20 & $-2,1638$ & 21 & 1,0843 & 7 & $-1,254$ & 21 \\
\hline gostyniński & $-2,6131$ & 23 & $-2,5984$ & 26 & 0,5194 & 18 & $-1,785$ & 22 \\
\hline przasnyski & $-2,4164$ & 22 & $-3,4877$ & 30 & 0,2608 & 21 & $-1,871$ & 23 \\
\hline pultuski & $-3,0165$ & 26 & $-2,2461$ & 25 & $-0,3345$ & 26 & $-1,989$ & 24 \\
\hline płoński & $-2,8834$ & 25 & $-2,7666$ & 27 & $-0,1268$ & 25 & $-2,003$ & 25 \\
\hline garwoliński & $-3,0194$ & 27 & $-2,1922$ & 23 & $-0,7586$ & 30 & $-2,011$ & 26 \\
\hline sierpecki & $-2,7146$ & 24 & $-3,7646$ & 35 & 0,5604 & 15 & $-2,053$ & 27 \\
\hline płocki & $-3,1798$ & 28 & $-2,1833$ & 22 & $-0,7641$ & 31 & $-2,092$ & 28 \\
\hline żuromiński & $-3,2343$ & 29 & $-3,6944$ & 34 & 0,7970 & 12 & $-2,288$ & 29 \\
\hline ostrowski & $-3,3339$ & 30 & $-3,0162$ & 29 & $-0,6996$ & 29 & $-2,323$ & 30 \\
\hline łosicki & $-3,6247$ & 31 & $-2,2178$ & 24 & $-4,4625$ & 42 & $-2,602$ & 31 \\
\hline sokołowski & $-4,1805$ & 33 & $-2,9332$ & 28 & $-1,4525$ & 35 & $-2,796$ & 32 \\
\hline radomski & $-4,0097$ & 32 & $-4,3842$ & 37 & 0,2605 & 22 & $-2,854$ & 33 \\
\hline makowski & $-4,2040$ & 34 & $-3,5638$ & 31 & $-0,5892$ & 28 & $-2,862$ & 34 \\
\hline ostrołęcki & $-4,5996$ & 35 & $-3,8789$ & 36 & $-1,1630$ & 33 & $-3,166$ & 35 \\
\hline białobrzeski & $-5,0595$ & 36 & $-3,6738$ & 33 & $-1,6453$ & 37 & $-3,398$ & 36 \\
\hline węgrowski & $-5,1159$ & 37 & $-3,6559$ & 32 & $-1,6604$ & 38 & $-3,425$ & 37 \\
\hline szydłowiecki & $-5,1354$ & 38 & $-5,8224$ & 41 & $-1,1249$ & 32 & $-3,803$ & 38 \\
\hline siedlecki & $-6,0975$ & 40 & $-4,7585$ & 38 & $-1,7105$ & 39 & $-4,138$ & 39 \\
\hline zwoleński & $-6,1615$ & 41 & $-5,5149$ & 39 & $-1,4982$ & 36 & $-4,297$ & 40 \\
\hline przysuski & $-5,9262$ & 39 & $-6,4795$ & 42 & $-1,9856$ & 40 & $-4,394$ & 41 \\
\hline lipski & $-6,3359$ & 42 & $-5,5434$ & 40 & $-2,3223$ & 41 & $-4,453$ & 42 \\
\hline
\end{tabular}

$W_{S}$ - wskaźnik syntetyczny.

Źródło: badania własne. 


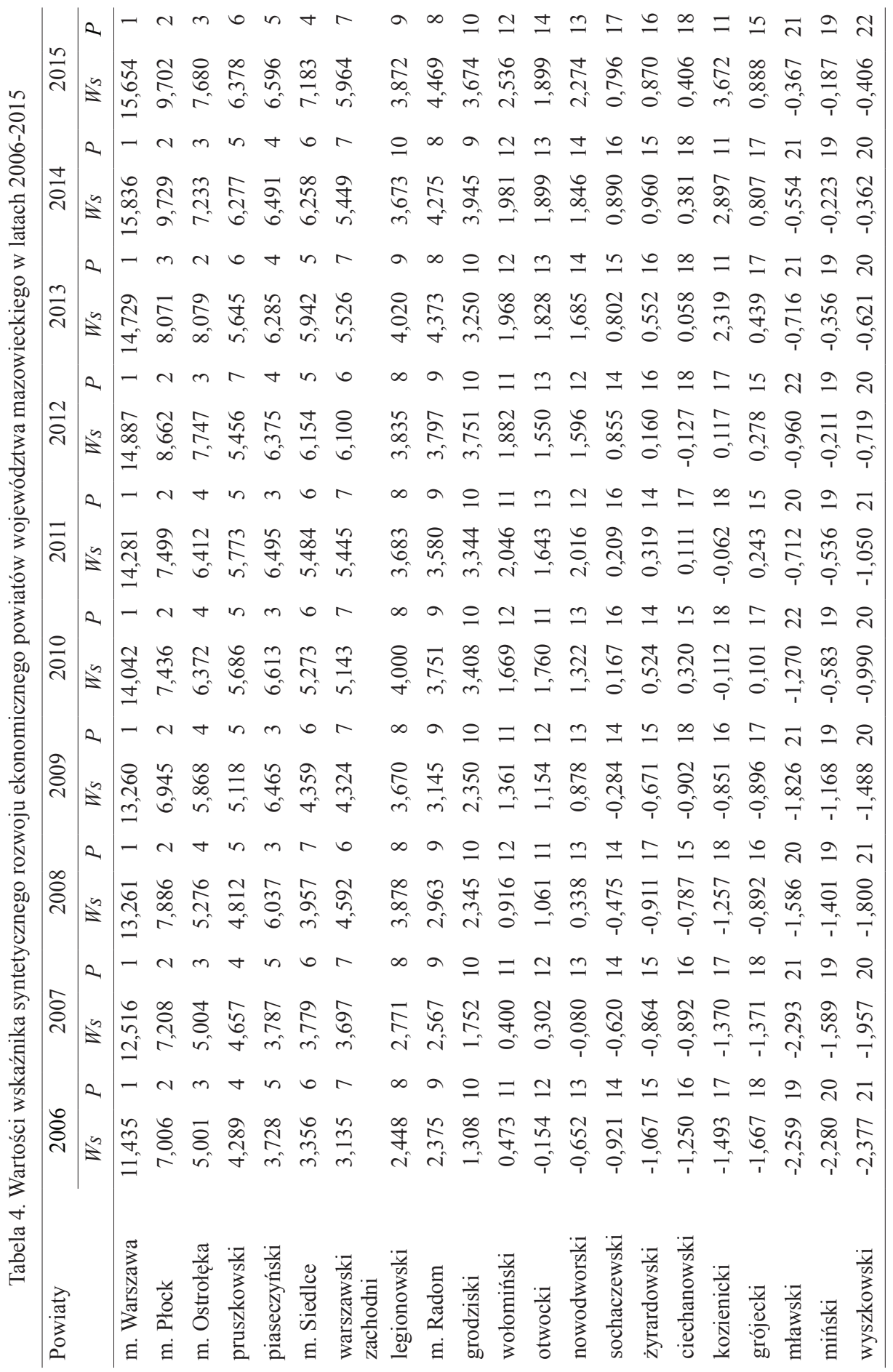




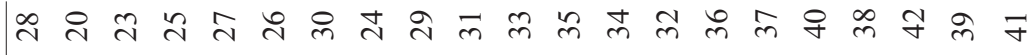
点

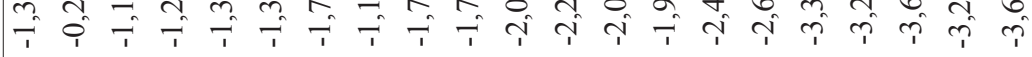

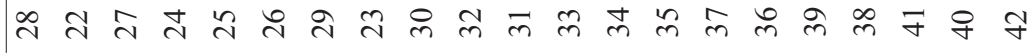

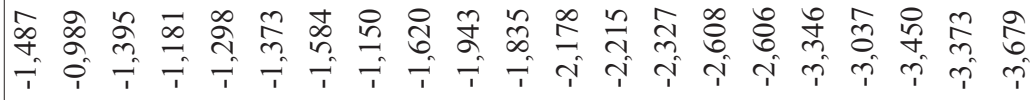

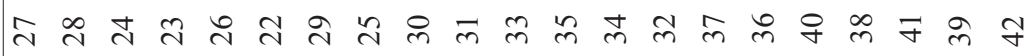

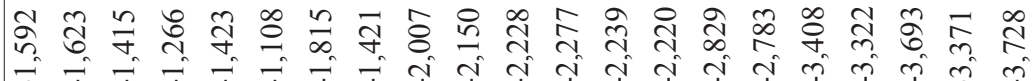

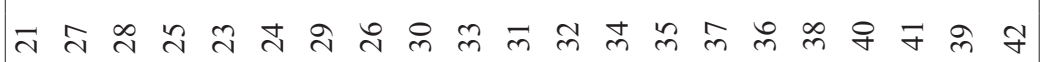
च

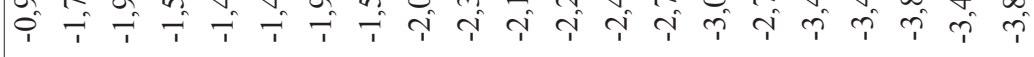
৯

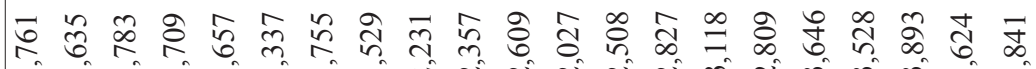

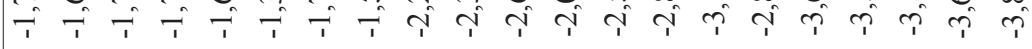

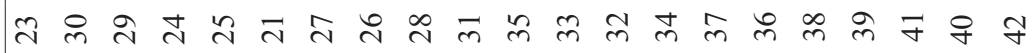

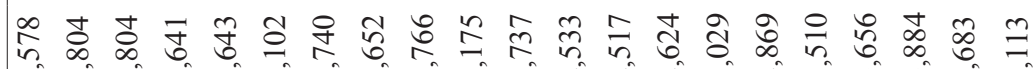

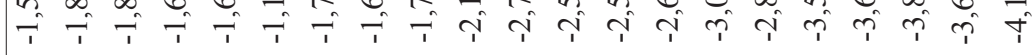
तี

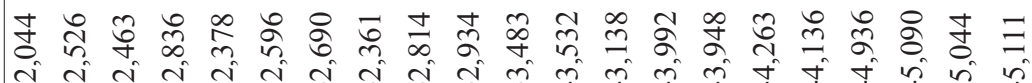

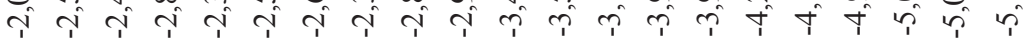
สิ 斿

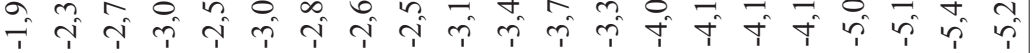

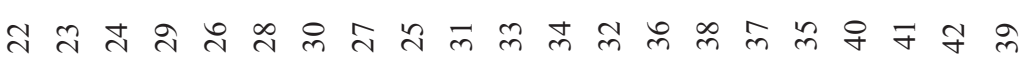
iิ

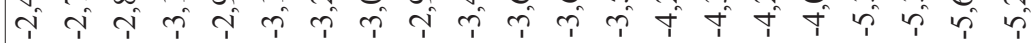

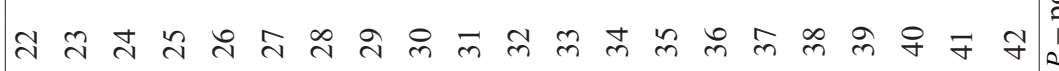

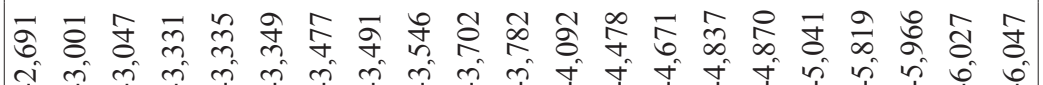

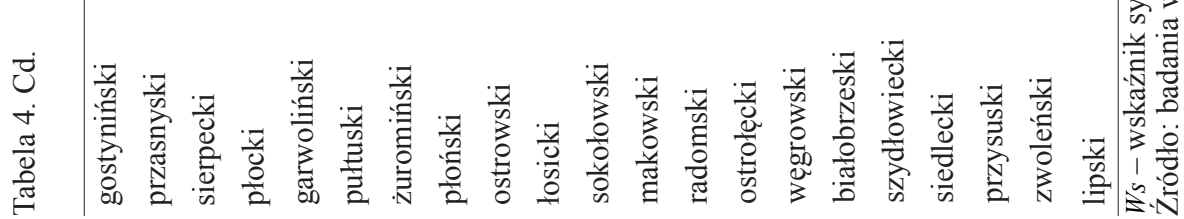


podstawie tych wyników należy stwierdzić, że w 2015 roku zwiększyło się zróżnicowanie między powiatami pod względem ich rozwoju ekonomicznego. Przechodząc do pozycji rankingowych badanych powiatów, należy stwierdzić, że w latach 2006-2015 największa poprawa nastąpiła w powiecie kozienickim (o 6 pozycji) i w powiecie płońskim (o 5 pozycji), a największe pogorszenie odnotowano w powiecie gostynińskim (o 6 pozycji) i powiecie sochaczewskim (o 3 pozycje). Analizując pozycje rankingowe poszczególnych powiatów należy podkreślić, że były one podobne we wszystkich badanych latach. Wynikało to głównie z tego, że rozwój gospodarczy jest procesem powolnym i długofalowym.

\section{PODSUMOWANIE}

1. Z przeglądu badań wynika, że na rozwój ekonomiczny wpływa wiele różnorodnych czynników, dlatego przy jego szacowaniu powinno się wykorzystywać wielowymiarowe wskaźniki syntetyczne, które pozwalają na ustalenie pozycji badanych obiektów na tle innych występujących obiektów.

2. Z przeprowadzonej analizy czynnikowej wynika, że głównymi determinantami rozwoju ekonomicznego powiatów województwa mazowieckiego były dochody i wydatki budżetów powiatów na 1 mieszkańca (czynnik 1.), zużycie energii elektrycznej i gazu z sieci na 1 mieszkańca (czynnik 2.) oraz udział mieszkań wyposażonych w wodociąg i łazienkę w ogólnej liczbie mieszkań (czynnik 3.).

3. Na podstawie oszacowanego wskaźnika syntetycznego wynika, że najsilniejszy rozwój ekonomiczny w województwie mazowieckim w latach 2006-2015 wystąpił w miastach na prawach powiatów, tj. w Warszawie, Płocku i Ostrołęce oraz w powiatach piaseczyńskim i pruszkowskim, a najsłabszy w powiatach lipskim, przysuskim, zwoleńskim i siedleckim. W badanym okresie wzrosło zróżnicowanie rozwoju ekonomicznego między badanymi powiatami.

4. Porównując zmiany wartości wskaźnika syntetycznego rozwoju ekonomicznego powiatów województwa mazowieckiego w latach 2006 i 2015, należy stwierdzić, że były one dodatnie. Największe zmiany między badanymi latami stwierdzono w miastach na prawach powiatów, tj. w Warszawie i Siedlcach oraz w powiatach ziemskich: kozienickim, nowodworskim i piaseczyńskim. Z kolei najmniejsze zmiany wskaźnika syntetycznego odnotowano w powiatach: gostynińskim, legionowskim, ciechanowskim, szydłowieckim i sochaczewskim. Pod względem zajmowanych pozycji największą poprawę w rankingu odnotowały powiaty: kozienicki, płoński, grójecki, ostrołęcki i przasnyski, a największe pogorszenie: gostyniński i sochaczewski. W większości powiatów zmiany pozycji w rankingu nie przekraczały 2 pozycji.

5. Występujące mierniki rozwoju gospodarczego cały czas powinny być udoskonalane, aby jak najbardziej odzwierciedlać rzeczywistą jakość życia ludności. Wiarygodne indeksy rozwoju ekonomicznego powinny stanowić cenne źródło informacji dla jednostek samorządu terytorialnego w prowadzeniu polityki społeczno-gospodarczej w krótkim i długim okresie. 


\section{LITERATURA}

Bloom David, David Canning, 2009: Cumulative causality, economic growth, and the demographic transition, [w] Population Matters: Demographic Change, Economic Growth, and Poverty in the Developing World, red. Nancy Birdsal, Allen Kelley, Steven Sinding, Oxford University Press.

Bloom David, David Canning, Kevin Chan, Luca Dara Lee, 2014: Higher Education and Economic Growth in Africa, „International Journal of African Higher Education”, t. 1, nr 1, s. 23-57.

Calderon Cesar, Serven Luis, 2008: Infrastructure and economic development in Sub-Saharan Africa, „Policy Research Working Paper”, The World Bank, Development Research Group, Macroeconomics and Growth Team nr 4712.

Dyson Tim, 2010: Population and Development: The Demographic Transition, London and New York, Zed Books.

Fan Shenggen, Xiaobo Zhang, 2004: Infrastructure and regional economic development in rural China, „China Economic Review”, nr 15, s. 203-214.

Gyimah-Brempong Kwabena, Oliver Paddison, Workie Mitiku, 2006: Higher education and economic growth in Africa, „The Journal of Development Studies”, t. 42, nr 3, s. 509-529.

Headey Derek, Andrew Hodge, 2009: The effect of population growth on economic growth: a meta-regression analysis of the macroeconomic literature, „Population and Development Review”, t. 35, nr 2, s. 221-248.

Kim Hyun Jeong, Chen Ming-Hsiang, Jang SooCheong, 2006: Tourism expansion and economic development: The case of Taiwan, „Tourism Management”, t. 27, nr 5, s. 925-933.

McKeown Thomas, 1976: The Modern Rise of Population, London, Edward Arnold ltd.

Myrdal Gunnar, 1973: Against the Stream, New York, Pantheon Books.

Pastusiak Radosław, 2011: Specjalne strefy ekonomiczne jako stymulator rozwoju gospodarczego, Wyd. Uniwersytetu Łódzkiego, Łódź, s. 25.

Pawlas Iwona, 2015: Społeczno-ekonomiczny rozwój krajów Unii Europejskiej-analiza porównaw$c z a$, „Studia Ekonomiczne. Zeszyty Naukowe Uniwersytetu Ekonomicznego w Katowicach”, nr 228, s. 61-75.

Pegkas Panagiotis, 2014: The Link between Educational Levels and Economic Growth: A Neoclassical Approach for the Case of Greece, ,International Journal of Applied Economics”, t. 11, nr 2, s. 38-54.

Petrakis Panagiotis, Dimitrios Stamatakis, 2002: Growth and educational levels: a comparative analysis, „Economics of Education Review”, nr 21, s. 513-521.

Piasecki Ryszard, 2003: Rozwój gospodarczy a globalizacja: ekonomia rozwoju w zderzeniu z rzeczywistościa, Wyd. PWE, Warszawa.

Simon Julian, 1981: The Ultimate Resource, New Jork, Princeton University Press, Princeton.

Sindig Steven, 2009: Population, poverty and economic development, Bixby Forum, The World in 2050, Berkeley, California, January 2009.

Siudek Tomasz, 2013: Rozwój gospodarczy-aspekty teoretyczne i praktyczne, „Roczniki Naukowe Stowarzyszenia Ekonomistów Rolnictwa i Agrobiznesu", t. 15, z. 5, s. 266-274.

Siudek Tomasz, 2008: Wpływ kredytów rolniczych udzielanych przez banki spółdzielcze na rozwój rolnictwa $w$ Polsce. ,Zeszyty Naukowe SGGW. Ekonomika i Organizacja Gospodarki Żywnościowej", t. 66, s. 37-47.

Stec Małgorzata, 2004: Analiza porównawcza poziomu rozwoju społeczno-gospodarczego Polski na tle krajów Unii Europejskiej i krajów do niej kandydujących, „Nierówności Społeczne a Wzrost Gospodarczy", nr 5, s. 9-22.

Yao Shujie 2000: Economic Development and Poverty Reduction in China over 20 Years of Reforms, „Economic Development and Cultural Change”, t. 48, nr 3, s. 447-474. 


\section{Tomasz Siudek, Katarzyna Drabarczyk \\ ECONOMIC DEVELOPMENT OF DISTRICTS IN MAZOVIA PROVINCE \\ - MULTIDIMENSIONAL ANALYSIS \\ Summary}

The purpose of the work was to determine the level of economic development of districts in Mazovia Province using the author's synthetic index. The obtained data show that in the years 2006-2015 the best districts in terms of economic development were cities with district rights: Warsaw, Plock and Ostrolęka, as well as districts bordering Warsaw, such as piaseczynski and pruszkowski. By contrast, the districts in the south and east of Mazovia Province, such as: lipski, przysuski, zwoleński, siedlecki and szydlowiecki, were the worst in terms of economic development.

Adres do korespondencji:

Dr hab. Tomasz Siudek, prof. SGGW

Szkoła Główna Gospodarstwa Wiejskiego w Warszawie

Wydział Nauk Ekonomicznych, Katedra Finansów, Zakład Bankowości ul. Nowoursynowska 166, 02-787 Warszawa e-mail: tomasz_siudek@sggw.pl 